\title{
ELECTRONIC COMMERCE DURING COVID-19: AN ANALYSIS OVER HOW ONLINE MEDIUM HELPS DIFFERENT INDUSTRIES IN A PANDEMIC CONTEXT
}

\author{
Elena MIRCEA \\ Bucharest University of Economic Studies, Bucharest, Romania \\ elenamircea94@gmail.com
}

\begin{abstract}
On Wednesday, March $11^{\text {th }}$, the whole world was put on hold when the World Health Organization officially announced the beginning of a new pandemic generated by the SARS-COV-2 Coronavirus. Even if rumors about a new coronavirus appeared in Wuhan, China were spread starting with $12^{\text {th }}$ of December 2019, only on the last day of the year Chinese government officially reported the first cases. The outbreak came with severe consequences for society, people's health and for the global economy, leading to dramatic changes in consumer behaviour. At this point, it can be considered that studies over this topic are in the incipient stage, as we barely overcame the first wave. Analysts are saying that we are facing the beginning of the second wave, considered to be much stronger. Specific literature and analysis are time dependent, limited by the coronavirus actions and a final conclusion cannot be drawn yet. The aim of this paper is to analyse the impact of the pandemic caused by the new coronavirus on the economy, on people's economic behaviour taking into consideration the limitations generated by the unknown factors as ongoing studies over symptoms, treatments, side effects. Another goal is to present a general view over the way in which different industries reacted to an unstable economic and social environment, focusing on Romania in a globalized context. Consumer behaviour is reviewed during the government-imposed lockdown going towards commerce and electronic commerce, showing that the consumer behaviour changed during the last months, moving towards online alternatives.
\end{abstract}

Keywords: Consumer behaviour, e-commerce, Covid-19, Impact on Industry

\section{INTRODUCTION}

The COVID-19 outbreak reminded humanity that people are not immune to any type of catastrophe, like the actual pandemic situation and that those commonplace activities can instantly become something rare and difficult to achieve. Those kinds of viruses happened in the past and for sure this is not the last time when humanity faces a fatal virus. Specialists claimed that since people live closer and closer to animals, any virus can transform and become dangerous for people, emerging in a new subtype as a result of the virus reassortment. This cannot be prevented, and we cannot say when it will be the next time, but our job is to be prepared and invest in the medical system, in research studies and in education. As C.W. Potter 
described in (Potter, 2001), pandemics seem to occur every 10 to 50 years and due to globalization and people traveling more often, spreading the virus is easier than in the past.

During the TED 2015 conference, Bill Gates addressed an issue that seemed quite far away from reality at that point in time. In "The next outbreak? We're not ready" he spoke about a new possible global catastrophe describing it as an influenza virus and not as a nuclear war as expected. He mentioned that the problem is not "if', but just "when", emphasizing the idea that this will come sooner or later and the problem is not that we have a system, but that does not work well enough, but that we don't have a system at all (TED Conference, 2015).

Analysing the last millennium pandemics, economists observed that those periods have been associated with subsequent low returns to assets, people tend to be less interested in investing, focusing on saving capital (Jordà et al., 2020). From a financial perspective this behaviour reduces the economic growth.

This pandemic had an enormous impact on our lives, physically and mentally and the effects are far to be over. Most of the countries declared a major lockdown, first by closing their borders and then keeping everyone inside their homes, limiting human interactions as much as possible. For some of them, those measures came a little too late and the disaster could not be avoided, central and eastern Europe had the advantage of time and the bad experience of Italy and Spain, so maybe this is why Romania was closed from the very beginning. Rules were not easy to follow, people thought it was just a matter of time, so when the situation escalated, they started to be nervous, anxious and not to follow the rules. Other countries decided to adopt another tactic, like Sweden who decided not to kill the economy and to let people enjoy their normal lives. In the end everything resumed at the human capacity to adapt to the new normality, not knowing when and especially if things will be back as they used to be.

\section{CONSUMER BEHAVIOUR DURING COVID-19 PANDEMIC}

As citizens are asked to stay home and respect social distance, specialists become worried about other mental aspects like depression, negativity and loneliness, harmful feelings that can appear after long periods of isolation, recommending to find activities that involve energy consumption and releasing stress. People changed and their behaviour also, some of them learned how to cook, others started to read more or to work out, but definitely they adapted to the new situation, alongside with their shopping preferences. Everything moved online: work, school, grocery and consumer behaviour changed dramatically, but using electronic commerce.

E-commerce represents the economic activity of buying and selling goods and services through the internet, using web browsers and mobile applications. Commonly associated with the physical sale of a product, e-commerce describes a wide range of activities such as online banking, online booking of 
services, online payments and money transfer, but also online activities between individuals and the public sector.

The literature (Boyaci \& Baynal, 2016) presents six types of electronic commerce that describe any transaction done via internet:

- Business-to-Business (B2B) - describes the electronic transactions that are done between two companies;

- Business-to Consumer (B2C) - one of the most traditional forms of e-commerce, describes sales activities between a company and an ordinary consumer. Individuals obtain the advantage of buying goods that typically cannot be found in their area.

- Consumer-to-Consumer (C2C) - transaction take place between two consumers by using online platforms (e.g. PayPal, OLX, La Jumate) often conducted by social networks (e.g. Facebook Markert);

- Consumer-to-Business (C2B) - not so common, when an individual offers products or services to a company;

- Business-to-Administration (B2A) - this category refers to those transactions that happens between companies and the public sector;

- Consumer-to-Administration (C2A) - transactions between individuals and public administration.

The usage of e-commerce is constantly growing, and the pandemic situation helped by increasing its popularity. Maybe this virus came at a perfect time from an information technology perspective, as many companies managed to stay on the market and people kept their jobs. Imagine only having this lockdown 10 or 15 years ago when from a technical perspective, internet usage was not so developed. According to Statista, almost 4.57 billion people were active internet users as of July 2020 , meaning $59 \%$ of the global population (Statista, 2020e).

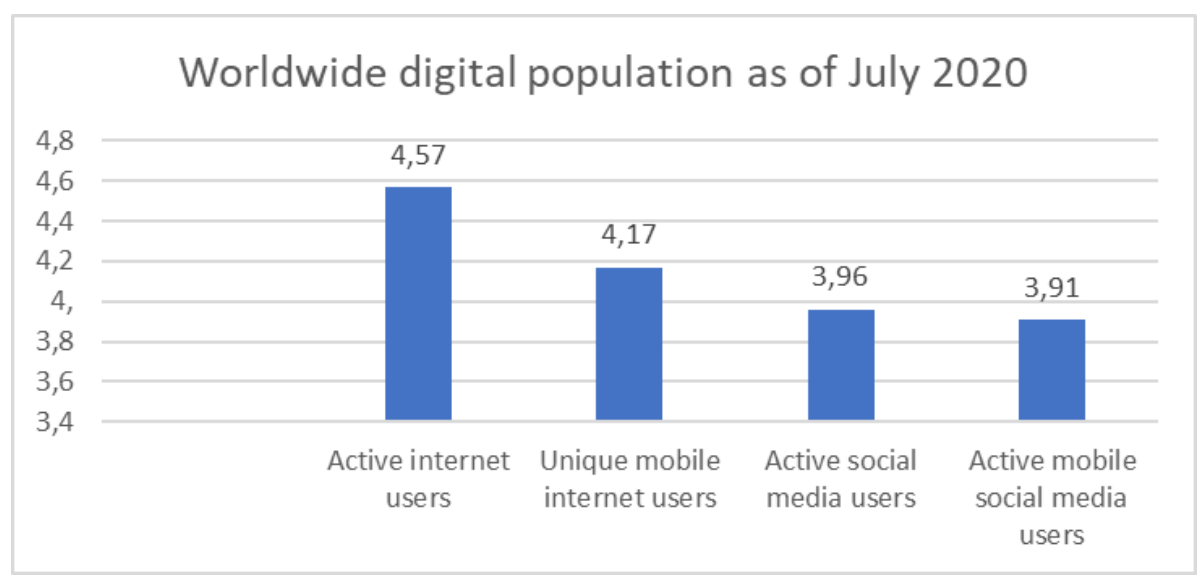

FIGURE 1. Worldwide Internet Usage

Source: (Statista, 2020e) 
As per figure 1, more than 4.17 billion people are unique mobile internet users, meaning that the usage of smartphones raised to the point of creating a sub-segment of electronic commerce, mobile commerce (abbrv. m-commerce).

M-commerce is a form of e-commerce, specialized in buying and selling goods or services using a handheld device such as a smartphone or a tablet. One of the biggest advantages is that the user is not limited to any physical space for the laptop or computer, no cables and special internet connections (Pantelimon et al., 2020). Over the years, wireless devices became faster and more secure and the costs of $3 G$ and $4 G$ are affordable in many countries all over the globe, among the fact that $5 \mathrm{G}$ devices are already on the market.

Another advantage of using mobile devices is that most stores developed extremely intuitive applications, designed to be time efficient, so in two or three steps your order is already placed. They store all your personal data, such as name, address and card details, many of them have no shipping costs, so your shopping cart is delivered home without efforts from your side. One disadvantage could be that mobile software is always updated and improved, meaning that those applications must be constantly adapted to the new functionalities, translating into higher development costs.

The global pandemic is affecting consumer behaviour, and this reflects in online traffic on different market sectors. So, while maintaining social distancing, people changed completely their preferences. In June 2020 online traffic in the supermarket segment increased by $60.7 \%$ compared with the reference period January-February 2020, in contrast with the tourism sector where trafic decreased with $47.5 \%$ (Statista, 2020b).

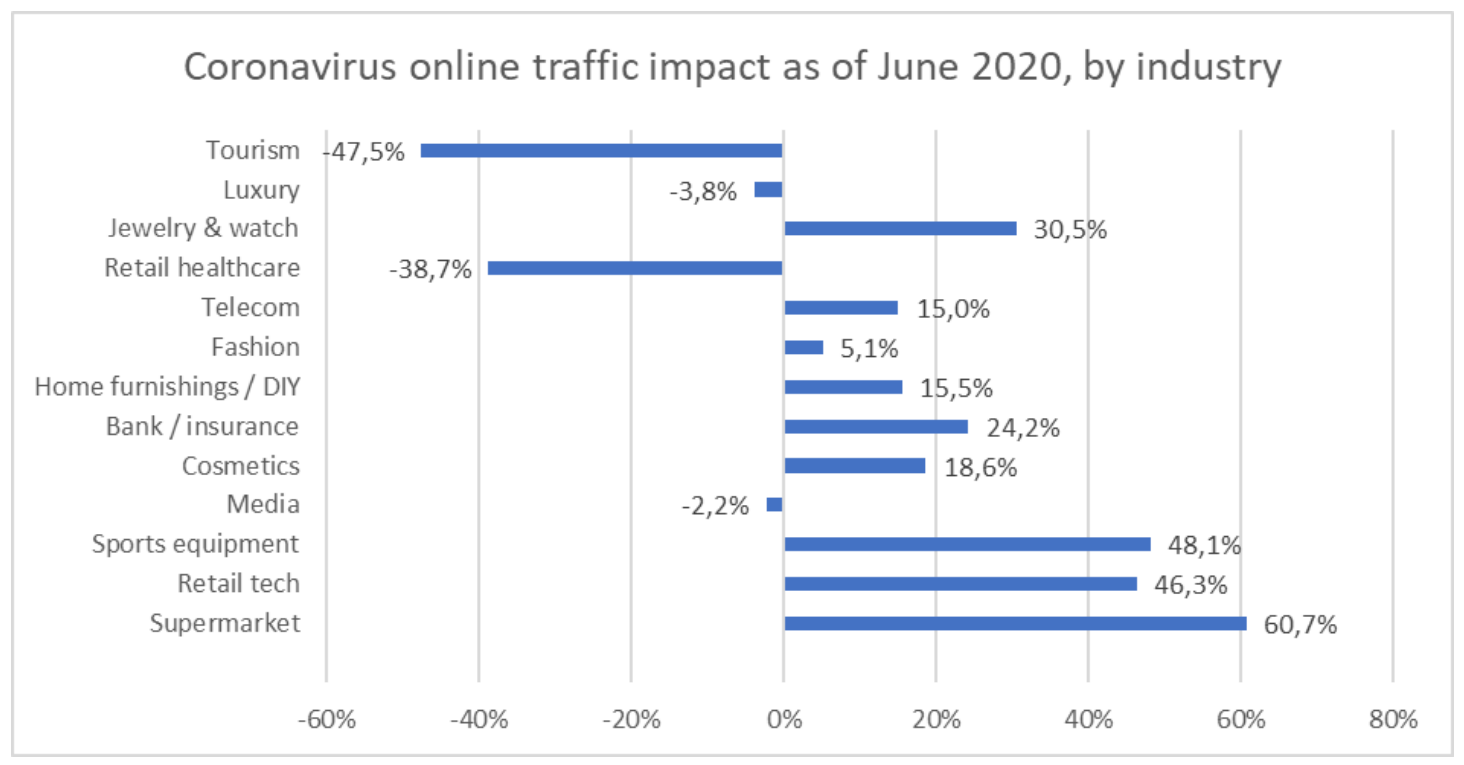

FIGURE 2. Online traffic by industry sectors

Source: (Statista, 2020b) 
Tourism sector was by far the most affected by the SARS-COV-2 virus, the difference between this industry and Fashion and Cosmetics is that those two were able to adapt by producing masks and sanitisers, while Tourism was completely closed for months.

Definitely specific grocery activities were moved to online and this sector managed to maintain the first position for the whole pandemic period, followed by sport equipment online shops and technology. As recommended, people started to invest in their health, by being more active and increasing online traffic on specific websites. Most of the companies were able to adjust and convert their way of work, by moving their operations in home offices so extra technical equipment was needed, explaining the growth for the technology sector by almost $46.3 \%$.

Regardless of the dangerous situation and the drastic measures, grocery stores remained open, but people were asked by their governments to lower the time spent in a supermarket. According to a report (Statista, 2020c) done in four counties on 9931 respondents, the rules were obeyed, especially in Italy where $79 \%$ of the respondents spent less time doing their grocery. It can be said that this is a predictable behaviour, since Italy is one of the most affected countries by this virus.

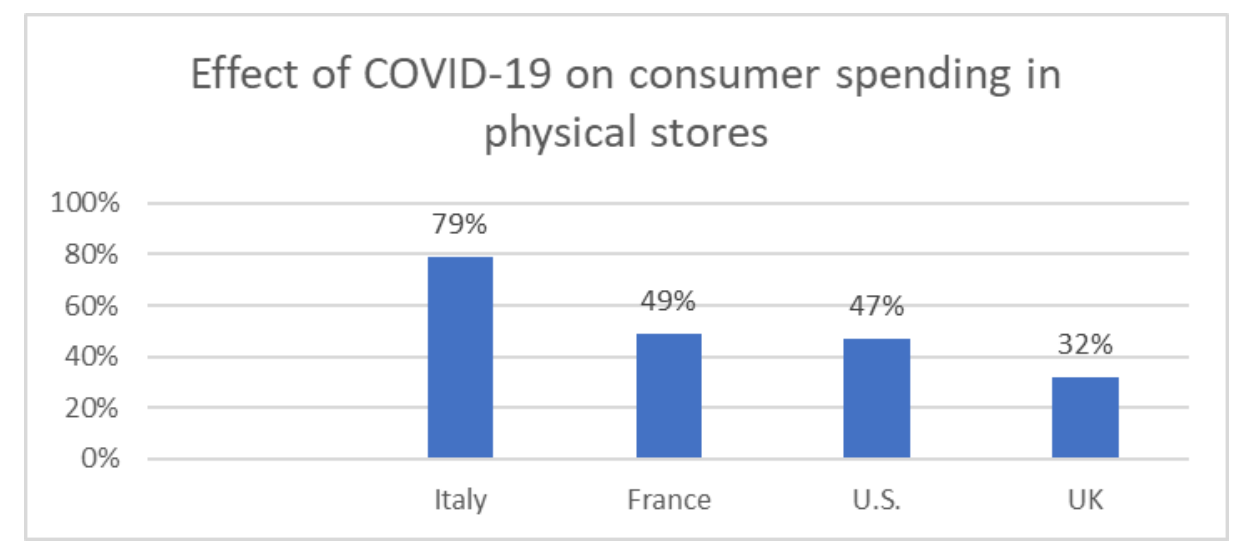

FIGURE 3. COVID-19 effects on time spent in stores

Source: (Statista, 2020c)

An online survey, done on 10000 respondents analyzed and compared the frequency of online purchasing during pandemic. The analysed periods were March $15^{\text {th }}$ versus the previous month, in 12 of the most affected countries. As shown in figure 4, residents from Vietnam were the most responsive on ecommerce, $57 \%$ of them choosing online methods, compared with Germany where only $12 \%$ of the population changed their behaviour (Statista, 2020a). 


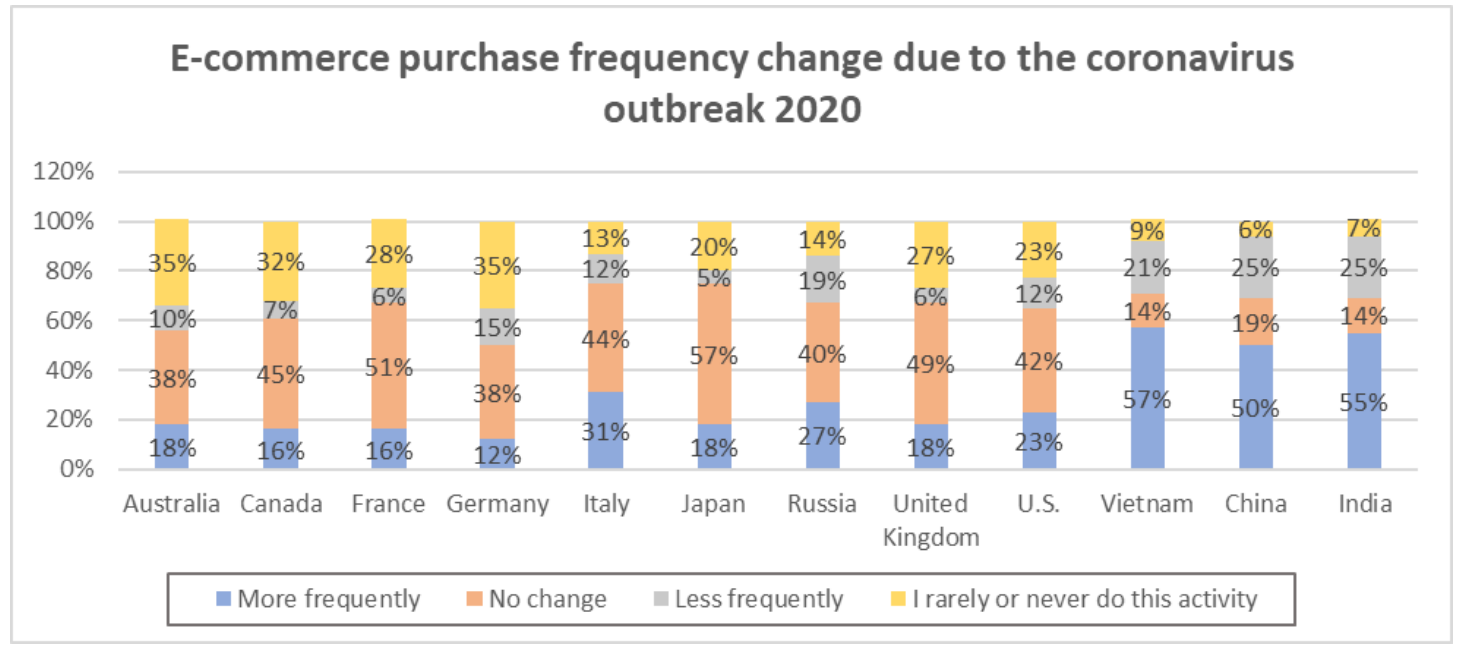

FIGURE 4. Online Purchase frequency

Source: (Statista, 2020a)

By mid of September the world exceeded 30 million cases of SARS-COV-2 coronavirus and many countries that lifted isolation measures and other strict restrictions reported to face the second wave of the virus, so the call for a vaccine is louder than ever. Europe and the United States are worried about the winter season coming, a season that is already associated with severe flus and colds. At this point there are 615 drugs and vaccines in development, but 487 of these are still in a preclinical phase. In phase III of testing there are known 22 variants and only one is in the pre-registration phase (Statista, 2020d).

\section{POSITIVE AND NEGATIVE EFFECTS OVER VARIOUS INDUSTRIES}

The main objective is to analyse the impact of this virus over different industries, focusing on Romania while presenting global perspectives and general principles available worldwide. The new coronavirus is having visible effects on the global economy, rapid contraction of the economy, increased unemployment rate and collapse of tourism, restaurants and airlines, effects with immediate impact over the population. Specialists are raising signals over the middle and long-term effects that could affect the economic landscape for the next years or decades (Jordà et al., 2020). Influences over the natural rate of interest can be seen even after 40 years (Jordà et al., 2020), people tend to live a simpler life and to save money, a situation that is associated with subsequent low return on assets. Historically speaking, the actual economy could wait between 1 and 40 year so that the natural rate returns to the expected level without having a global pandemic.

The leading discussions were around the economy's shape recovery. Historically speaking after most of the previous pandemics the recovery had a V-shape (Ernst \& Young, 2020), main economic activities coming up strongly after the first wave of illness was over. Six of the past seven recessions followed a Vshaped pattern (Ernst \& Young, 2020), even though different opinions are discussed among economists. A 
V-shape recovery is desired and expected by the majority of the specialists, but analysts are also discussing U-shape, meaning that could take years to overcome the crisis and the most pessimistic of them are talking about a L-shape model. According to an EY report, in March 2020, 38\% of the interviewed executives expected a $\mathrm{V}$-shaped recovery, $54 \%$ of the respondents prepared for a U-shaped one and $8 \%$ for an L-shaped (Ernst \& Young, 2020).

As unexpected as it can sound, certain industries managed to obtain profit during this period, while others were completely down for many months. Some companies managed to increase their turnover, but some went bankrupt. One of the most affected sectors is tourism, in March hotel business owners hoped that by the end of May, things will come to normal and hotels will be able to receive their guests as usual. According to Romanian National Institute of Statistics, arrivals in hotels and overnight stays decreased with $76.4 \%$ in June 2020, compared with the same period of 2019. Romanian people's prefered to stay inside their country, so the departures abroad fell by $68.1 \%$, but also less foreign visitors came to our country, resuming a $68.7 \%$ decrease of tourists (Oancea, 2020). Restaurants were closed for more than two and a half months, translating in at least $80 \%$ losses during the summer months, owners relying on home deliveries (Rosca, 2020).

The same situation happened also in Europe, where the tourism services sector fell by $75 \%$ in June compared with February same year (travel agencies $-83.6 \%$, air transport $-73.8 \%$, accommodation $-66.4 \%$ and restaurants -38.4\%) (Eurostat, 2020).

Besides the impact of the usual lockdown and closure imposed by the restrictions from the tourism sector, important financial losses were determined by the cultural and entertainment sectors (museums, theaters, cinemas, festivals etc.). According to (Humeniuc, 2020), the cancellation of the most important music festival from Romania, Untold from Cluj-Napoca, comes with some estimated losses that exceed 60 million euro. For the same county, Cluj, needs to be considered extra losses, approximately 10 million euro from Electric Castle and 8 milions from TIFF, the largest film festival from the country.

One of the biggest players on the fintech market, Revolut, made studies on different economic sectors of Romania and managed to summarize the positives and negatives economic effects of SARS-COV-2 coronavirus between March 14th and April 14th. For online entertainment, people spent more than 7.5 million euro, with $54 \%$ more than the previous month. The growth for online movie platforms was moderate, between $11 \%$ and $25 \%$, but in the online game sector the indicators are between $132 \%$ (Playstation) and 176\% (Steam Game) (lacob, 2020).

Transport sector crashed in the actual context, starting with ride sharing services, between $74 \%$ and $88 \%$, but public transport was by far the most affected, with a loss of $95 \%$ (lacob, 2020). This behaviour has multiple reasons, a major lockdown, schools were closed, many jobs moved to home offices and the ones 
that had to go to their regular offices were afraid to use a bus or a metro just because they did not want to go in public places.

As seen in figure 2, shopping moved to online worldwide and Romania followed the trend. While access in the regular shops was limited, online transactions value almost doubled, starting with eMag which growth reached $180 \%$, Decathlon at $143 \%$ and FashionDays at $63 \%$ (Economica, 2020). In addition, courier companies start hiring following an opposite trend by not finding enough people for their open positions.

By far the most spectacular and unexpected economic increase was known by the home delivery food applications, transaction value growth was over $90 \%$, Glovo even managed to expand its marked during Covid-19, by opening delivery points in new towns and hiring many people during an unstable economical time (Economica, 2020).

\section{CONCLUSION}

Through this research, a series of journal papers, statistic websites and periodical articles were analysed in order to find out how the new coronavirus changed the economic system all over the word and especially in Romania. Starting with the beginning of 2020 a new threat appeared and humanity was definitely not ready for it. Without being fully aware of the danger and the enormous impact, people in general believed that in one- or two-months things will be back to normal. Almost seven months later specialists are raising concerns and announce that our normality might never be the same. Besides the economic impact, people's health problems and the major lockdown, traumas will remain in people's minds many years from now on.

Electronic commerce and mobile commerce had a continuous increase in the market during the past few years and they are still growing as many people found out only during this pandemie how comfortable online shopping can be. The normal fears as "what if I don't like the product" or "what if it does not fit me" were easily dismantled by the retail specialists, offering free return services. In an age of technology, good marketing saved a business and only those who were able to adapt managed to remain competitive.

For some industries the novelty came from the manager's openness to work from home. Some companies already offered this opportunity, so their employees were able to work remote for one or two days in a week, especially in the information technology sector. Starting with March 2020 this possibility became the primary way in which organizations could work at full capacity, so even more offices moved to personal homes. Seeing that their employees are working on high capacity companies do not rush to open their offices, as the costs are smaller this way. Definitely, this pandemic changed our vision over the world, and we learned that threats can have different forms. The global economy is affected, people feel discouraged 
and at this point we are waiting for a permanent treatment, a vaccine that can help the world overcome this virus.

\section{REFERENCES}

Boyaci, A., \& Baynal, K. (2016). E-commerce research and applications: a proposal for classification and an updated literature review. 7th International Congress of Entrepreneurship, 810-827.

Economica. (2020). Deşi vizitele în magazine au scăzut, cheltuielile au crescut, iar serviciile de livrare au înregistrat creşteri fără precedent - studiu Revolut. Retrieved from Economica.net: https://www.economica.net/desi-vizitele-in-magazine-au-scazut-cheltuielile-au-crescut-iar-serviciilede-livrare-au-inregistrat-cresteri-fara-precedent-studiu-revolut_182935.html

Ernst \& Young. (2020). How do you find clarity in the midst of a crisis? Retrieved from EY Building a better working world: https://www.ey.com/en_gl/ccb/how-do-you-find-clarity-in-the-midst-of-covid-19crisis

Eurostat. (2020). Tourism senvices down by $75 \%$ in June compared with February. Retrieved from eurostat Your key to European statistics: https://ec.europa.eu/eurostat/web/products-eurostat-news//DDN-20200904-2

Humeniuc, R. (2020). 60 de milioane de euro va pierde Cluj-Napoca, dacă festivalurile din oraş vor fi anulate în 2020. Retrieved from Ziarul Financiar: https://www.zf.ro/companii/retail-agrobusiness/60de-milioane-de-euro-va-pierde-cluj-napoca-daca-festivalurile-din-19099684

lacob, A. (2020). Revolut: Pe ce și cum își cheltuie românii banii în timpul pandemiei. Mai mulți bani pe jocuri, mai puțini pe ridesharing. Retrieved from StartUP Cafe: https://www.startupcafe.ro/coronavirus-covid-19/revolut-cheltuie-romani-bani-pandemie-jocuriridesharing.htm

Jordà, Ò., Singh, S., \& Taylor, A. (2020). The longer-run economic consequences of pandemics. Retrieved from VOXEU: https://voxeu.org/article/longer-run-economic-consequences-pandemics

Oancea, D. (2020). Cum a afectat pandemia turismul românesc: Sosirile vizitatorilor străini au scăzut în iunie cu 68,7\% faţă de iunie 2019. Retrieved from Ziarul Financiar: https://www.zf.ro/eveniment/cuma-afectat-pandemia-turismul-romanesc-sosirile-vizitatorilor-19460871

Pantelimon, F.-V., Georgescu, T.-M., \& Posedaru, B.-S. (2020). The Impact of Mobile e-Commerce on GDP: A Comparative Analysis between Romania and Germany and how Covid-19 Influences the eCommerce Activity Worldwide. Informatica Economică, 27-41.

Potter, C. (2001). Division of Molecular and Genetic Medicine. Journal of Applied Microbiology, 572579.

Rosca, C. (2020). Radiografia industriei de restaurante în pandemie. Mai bine de jumătate dintre jucători au pierdut cel puţin $80 \%$ din business după redeschidere, iar livrările reuşesc arareori să contribuie $\mathrm{cu}$ peste $30 \%$ la încasări. Retrieved from Ziarul Financiar: https://www.zf.ro/companii/retail-agrobusiness/radiografia-industriei-restaurante-pandemie-binejumatate-dintre-19445223

Statista. (2020a). Change in e-commerce usage to purchase products normally bought in-store due to coronavirus (COVID-19) worldwide as of March 15, 2020, by country*. Retrieved from https://www.statista.com/statistics/1105597/coronavirus-e-commerce-usage-frequency-change-bycountry-worldwide/ 
Statista. (2020b). Coronavirus global online traffic impact as of June 2020, by industry. Retrieved from https://www.statista.com/statistics/1105486/coronavirus-traffic-impact-industry/

Statista. (2020c). Have you already reduced your spend on day-to-day in-store purchases due to the coronavirus? Retrieved from https://www.statista.com/statistics/1106000/coronavirus-in-storespending-behavior-of-consumers-worldwide/

Statista. (2020d). Number of coronavirus (COVID-19) drugs and vaccines in development worldwide as of September 18, 2020, by phase. Retrieved from https://www.statista.com/statistics/1119060/coronavirus-drugs-in-development-by-phase-worldwide/

Statista. (2020e). Worldwide digital population as of July 2020. Retrieved from https://www.statista.com/statistics/617136/digital-population-worldwide/

TED Conference (2015). The next outbreak? We're not ready [Recorded by Bill Gates]. 